
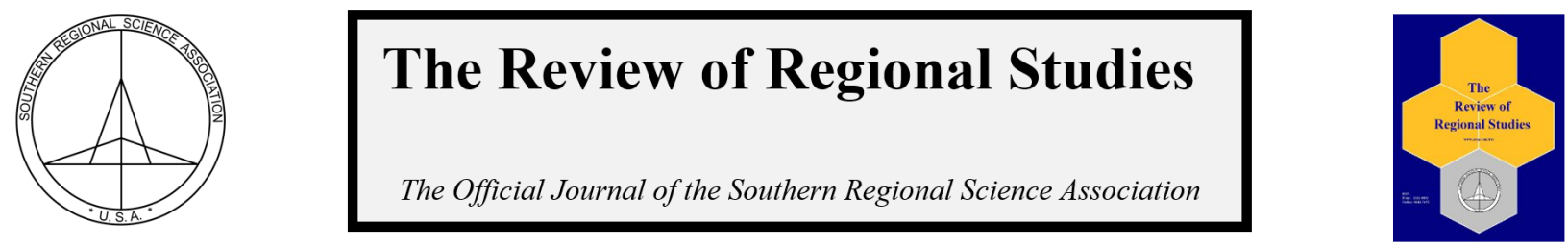

\title{
Factors Associated with Latino-Owned Business Survival in the United States*
}

\author{
Craig Wesley Carpenter ${ }^{\mathrm{a}}$, Scott Loveridge ${ }^{\mathrm{b}}$ \\ ${ }^{a}$ Department of Agricultural Economics, Texas AEMM University USA \\ ${ }^{b}$ Department of Agricultural, Food, and Resource Economics, Michigan State University, USA
}

\begin{abstract}
This article uses 127,000 observations from three confidential Census microdata sets at the individual firm and establishment level to investigate Latino-owned business survival. The merged microdata allows us to control for a wide array of personal, business, and regional characteristics. The analysis is based on hazard model. Relative to base categories, we find the following decrease in the odds of survival: Latinaowned, Puerto Rican owned, and selling to the federal government. Owner education and low barrier sectors have no effect, while start-up from personal savings increase the odds by 4 percent. The findings inform ways to expand regional economies through businesses operated by Latinos.
\end{abstract}

Keywords: entrepreneurship; self-employment; Latino; survival; microdata

JEL Codes: L25; M21; R11

\section{INTRODUCTION}

Small businesses and microenterprises account for approximately 18 percent of employment and create 900,000 jobs a year in the United States (Ramirez de Miess, 2009). In the U.S., the increased importance of micro and small enterprises is occurring in the context of a growing

\footnotetext{
*Thanks to Anil Rupasingha, Myriam Quispe-Agnoli, Julie L. Hotchkiss, Melissa Banzhaf, Margaret C. Leventsin, J. Clint Carter, Mark Fossett, Bethany Desalvo, the editors and reviewers, the Interuniversity Consortium for Political and Social Research, the TXRDC Consortium, and numerous conference participants for helpful comments. The authors gratefully acknowledge support for this research at the TXRDC and MRDC from the North Central Regional Center for Rural Development, the Department of Ag., Food, Resource Economics at Michigan State University, and USDA National Institute of Food and Agriculture, Hatch project 1014691. Any opinions and conclusions expressed herein are those of the authors and do not necessarily represent the views of the U.S. Census Bureau. All results have been reviewed to ensure that no confidential information is disclosed. Carpenter is an Assistant Professor and Extension Specialist in the Department of Agricultural Economics at Texas AM University, College Station, TX 77845. Loveridge is a Professor of Ag., Food, Resource Economics at Michigan State University, East Lansing, MI 48864. Corresponding Author: Carpenter E-mail: ccarpenter@tamu.edu
} 
Latino $^{1}$ population, which rose from 17 million in 1980 to 57 million in 2015 (Krogstad, 2016). While immigration is slowing, other demographic factors (age, fertility rate) mean the Latino component of the U.S. population will continue to increase (Gonzalez-Barrera, 2016; Krogstad, 2014). The historic and projected growth of the Latino population highlights the importance of understanding which factors affect the survival of Latino-owned businesses (LOB). Given the turbulent record of unemployment over the past decade, the possible employment benefits from more successful businesses arising from the Latino community are substantial.

The policy relevance of the role of Hispanics in broader U.S. society is highlighted by the change in newspaper mentions of "Hispanic" over the past several Presidential election cycles. According to LexisNexis Academic, in the first two weeks of November in election years, newspaper mentions increased consistently from 517 in 2000 to 2,451 in 2016. ${ }^{2}$ This growth is complemented by a nearly six-fold increase (from 64 in 2010 to 371 in 2017) in newspaper articles including the phrase "Latino Business" between 2010 and 2017. Therefore, understanding the role and condition of Hispanics in the economy is a dimension that is increasingly discussed as a public policy issue. LOBs are of growing empirical importance as well. The number of businesses owned by Hispanics is growing quickly relative to other ethnicities, with an increase of 46.3 percent between 2007 to 2012 (Bernstein, 2016), as opposed to 2 percent general establishment growth during the same period. Receipt growth rate for LOBs similarly outpaced that of all firms, with an increase of 35.1 percent to $\$ 473.6$ billion, compared to 11.7 percent growth to $\$ 33.5$ trillion for all firms (Bernstein, 2016).

From a policy perspective, it is important to know the impact of factors associated with Latino-owned business survival. Bates et al. (2011) find that LOBs tend to concentrate in relatively vulnerable sectors while Ahn (2011) find that LOBs are more likely to go out of business than White-owned businesses. So what causes an LOB to exit the market? Policy and non-governmental organization (NGO) efforts to promote LOBs via minority-oriented preferences in grants and loans are a matter of current debate and policy change. The success of new or existing policies and technical assistance are dependent upon understanding the determinants of location and growth of LOB, and the characteristics of business owners, businesses, and regions associated with LOB survival. Understanding these determinants may facilitate LOB activities more efficiently and effectively.

This article uses approximately $127,000^{3}$ observations from limited-access, confidential Census microdata. The microdata, accessed via a Federal Statistical Research Data Center

\footnotetext{
${ }^{1}$ In some cases, this article uses the term Hispanic rather than Latino because Census data categorizes individuals as Hispanic, rather than Latino. The terms are slightly different. Specifically, "Hispanic" is an ethnicity and focuses on Spanish-speaking origin and this includes Spain, but not Portuguese-speaking Brazil, while "Latino" refers to people of Latin American origin and thus includes Brazil, but not Spain. This paper acknowledges the difference between the two terms, but given the population of interest is Latino and that most individuals in the U.S. who are Hispanic are also Latino, this paper assumes results on Hispanic entrepreneurs in the U.S. are similar to results on Latinos in the U.S.

${ }^{2}$ Covering November 1-14 for each presidential election year from 2000-2016, newspapers mention the term Hispanic 517, 927, 1190, 1664, and 2451, respectively. Related terms behaved similarly. For example, newspapers mention "immigrants" 1049, 1755, 2050, 2589, and 5685, respectively.

${ }^{3}$ To protect confidentiality, the Census does not allow publishing the exact number of observations, so we round to the nearest thousand.
}

(c)Southern Regional Science Association 2019. 
(FSRDC) are merged information from the Survey of Business Owners, Longitudinal Business Database, and Integrated Longitudinal Business Database. We examine how business, business owner, and geographic factors affect LOB survival odds using survival analysis. Among this article's findings are (relative to the base categories): (1) owner education does not affect the likelihood of survival; (2) the only significant coefficient on start-up capital source is personal savings, which increases the odds of survival by 4 percent; (3) on average, having Puerto Rican ancestry decreases the odds of business survival; and (4) the low-barrier industries of construction and food service do not have significantly lower survival rates relative to other industries. Taken as a set, the findings imply that education, while important for other dimensions of incorporation into broader society and quality of life, may not be particularly relevant in prioritizing businesses for support services or loans, and that loans per se may not be the most important impediment to LOB survival. Lack of education may be limiting in other ways; however, such as growth, and this nuance may be an area for further research. Both the source of capital and Puerto Rican ancestry variables may be proxies for the broader notion of the owner's experience or ability to overcome institutional or financial barriers. More attention to hurdles overcome may help predict individual business persistence, and might be useful in allocating scarce resources for business development.

\section{LITERATURE REVIEW}

Researchers explored ethnic business ownership extensively over the past 20 years and found variations among businesses owned by various groups, but many of these took the form of case studies, involved small samples, or aggregate data. Robles and Cordero-Guzman (2007) note that LOB research could benefit from a large data sample. Studies using microdata (Lofstrom and Bates, 2009), faced limitations in their examination of comprehensive demographic and geographic differences with respect to the success of business owners of various ethnicities in the U.S. Rocha et al. (2015) conduct exceptional work using data on Portuguese entrepreneurs and Fairlie and Robb (2009) conducted studies on gender differences in business ownership and on minority-owned business using FSRDC data, but those studies have not focused on LOB. Despite not focusing on LOB, we leverage their findings to motivate this review in the following subsections.

The nature of an impediments to business survival may vary, or be similar, depending on the characteristics of the owner's ethnicity. For a variety of reasons, the experiences of black entrepreneurs are more likely to be related to those of Hispanic business owners versus whites, including discrimination, lower educational attainment, lower income levels, etc. There are several mechanisms through which these characteristics become relevant for Black business owners that LOB may also experience. For example, Robb and Fairlie (2007) find that the lack of prior work experience in a family business among Black business owners, perhaps by limiting their acquisition of general and specific business human capital, negatively affects Black business outcomes. As a group, LOB may have similar experiences in terms of unfamiliarity with the U.S. regulatory structures, but may have previous experience with self-employment. In terms of the importance of financial capital, Robb and Fairlie (2007) find that Black Americans have levels of wealth that are one-eleventh those of Whites and are much less likely to start businesses than Whites, which results in a substantially

(C)Southern Regional Science Association 2019. 
lower rate of business ownership. Further, they show that Black entrepreneurs who are successful in starting businesses invest much less capital at start-up on average than white entrepreneurs, which limits their ability to grow and succeed, while reducing the survivability of the businesses. It seems LOB should be similarly vulnerable to limited financing and personal wealth, but despite this Latinos have higher rates of business ownership than Blacks, indicating that limiting financing insufficiently explains white/Latino disparities in business ownership. Further, Bates and Robb (2013) note that minority businesses rely more heavily on financial institutions for loans than all other borrowing sources combined, but they experience higher costs and receive smaller loans than white firms when they borrow, and have their loan applications rejected more often. Another difference between Black-owned businesses and LOBs is that LOBs are more likely to use informal loans from friends or family and moneylenders (Raijman and Tienda, 2000; Haynes et al., 2008).

Several theories contribute to understanding the interactions between ethnic business owners and their environment. The disadvantage theory of entrepreneurship suggests that limited opportunities in the labor market (e.g. from language barriers, discrimination, or unemployment) cause people to seek self-employment (Light, 1979). The structuralist theory proposes that the entrepreneurship experience cannot result entirely from culture, but also from the interaction of the group characteristics (e.g. lack of formal training or co-ethnic mentors) of different ethnicities and the opportunity structures they experience (Waldinger, 1993). More recently, researchers have examined specific areas of interest. For example, researchers interested in minority ethnic business ownership have examined the impact of acculturation (Calo, 1995), the impact of financial resources (or lack thereof) (Cavalluzzo and Wolken, 2005), human and social capital (Hansen, 1995; Peters and Brush, 1996), networks (Walton-Roberts and Hiebert, 1997), the role of enclaves (Andersson and Hammarstedt, 2015), and motivation, business strategy, and community resources (Liu, 2012).

Following Robb and Fairlie (2009), we focus on the factors that we can measure with the Survey of Business Owners (SBO), Longitudinal Business Database (LBD), and Integrated Longitudinal Business Database (ILBD) microdata (which we discuss in the data section), such as human capital, business human capital, financial capital, and industry. The standard economic model predicts that these factors are relevant inputs in a firm's production process. The ethnic entrepreneurship literature refers to these as class resources. Although determinants of small business survival appear frequently in the literature, likely due to data access barriers, few studies attempt comprehensive investigations into the impact of 1) business-owner, 2) business, and 3) regional characteristics on business survival in general, or LOB in particular. The rest of this section reviews the literature on business survival by dividing past work into the aforementioned three topic area, with emphasis on how they may interact with ethnicity.

\subsection{Business-owner characteristics}

Human capital, as proxied by owner age and education, should theoretically increase survival (Cauchie and Vaillant, 2016). Owner age contributes positively to LOB survival (Lin et al., 2000; Van Praag, 2003; Fairlie, 2005), while findings on the impact of higher education are mixed, with some indicating a positive effect (Ganotakis, 2012; Millán et al., 2012;

(C)Southern Regional Science Association 2019. 
Oberschachtsiek, 2012; Lechmann and Schnabel, 2014), but others finding little or no effect (Taylor, 1999; Dahl and Reichstein, 2007; Georgellis et al., 2007; Asoni and Sanandaji, 2016). We found no literature directly addressing differences between Latina and Latino-owned business survival, but hypothesize that male-owned businesses tend to endure longer (based on general population studies). For example, Rosenthal and Strange (2012) find that female entrepreneurs (in general) may be less networked than their male counterparts and so derive less benefit from agglomeration. They may also have greater domestic burdens and therefore have higher commuting costs. Together, they then show that either of these forces can lead to the segregation of male- and female-owned businesses, with female entrepreneurs choosing locations farther from agglomerations and commuting shorter distances. There are limited or no reasons to suspect that these forces may not affect Latina business owners.

Economic theory predicts that labor is another important input into a firm's production process, and thus working longer hours may affect business survival. Indeed, Bates and Bates (1997) finds that the relative success of immigrant entrepreneurs disappears after adjusting for the number of hours worked by the owner.

\subsection{Business characteristics}

A major factor impacting Latino business survival is financial resources. Latinos primarily finance their businesses with personal savings and informal loans from friends or family and moneylenders (Raijman and Tienda, 2000; Haynes et al., 2008). One line of research in the sociological literature examines rotating credit associations and other types of financing, which emerge out of ethnic networks. Rotating credit associations allow people in the network to pool their savings and lend to individuals, many of whom start businesses with the borrowed capital.

Past studies on the impact of the firm activity sector are quite diverse (Dahl and Reichstein, 2007; Georgellis et al., 2007; Haapanen and Tervo, 2009). More recent studies examine why Latinos tend to concentrate in sectors perceived as relatively vulnerable, such as service (Robles and Cordero-Guzman, 2007; Puryear et al., 2008), construction, wholesale trade, and retail trade sectors (U.S. Census Bureau, 2010). Bates et al. (2011) find that businesses within low technology/barrier sectors face a greater likelihood of going out of business compared to other businesses. Robb and Fairlie (2009) suggest that racial differences in industry selection are probably due in part to preferences or to industry-specific knowledge and experience, or that some industries may have larger barriers created by existing networks and discrimination against outsiders.

\subsection{Regional characteristics}

This study includes regional and geographic controls for those factors that prior studies find to be significant. The standard economic model predicts that market area, income, and transportation costs (proxied by rurality) are all relevant to a firm's profit function. For example, Robb and Fairlie (2009) note some firms may have a wider market or trade relations with same-ethnicity countries, while locating in an urban area might similarly indicate a broader market area with greater growth potential. Further, Millan et al. (2014)

(C)Southern Regional Science Association 2019. 
find that the share of a population that is highly educated has a positive impact on business survival due to both demand and supply-side factors. Fertala (2008) finds that population density has a positive relationship with survival rates. Deller and Conroy (2016) show that, in general, there is a rural-urban spectrum of relative survival rates in which higher rurality associates with higher survival rates.

Another regional factor examined in numerous studies is the impact of the unemployment rate. The two competing forces here are the prosperity-pull effect and the recession-push effect, which occur as a result of opportunity entrepreneurship and necessity entrepreneurship, respectively (Millán et al., 2012). It is also possible that given both effects occur simultaneously, neither outweighs the other. Past results on the impact of the unemployment rate on self-employment have been mixed with support for the recession-push effect (Lin et al., 2000; Van Praag, 2003; Georgellis et al., 2007) and the prosperity-pull effect (Carrasco, 1999; Taylor, 1999; Fertala, 2008; Haapanen and Tervo, 2009).

We examine the validity of both hypotheses that have been previously tested on business owners in general, but not for LOB in particular as well as other hypotheses that are implied by previous literature but remain untested. This testing occurs with a larger sample size

and more extensive control variables derived from hitherto unavailable data. We list these hypotheses under the three topic areas described above:

\section{Business owner characteristics}

H1.1 Higher owner age increases the odds of LOB survival.

H1.2 Latina-owned businesses are less likely to survive than Latino-owned businesses.

H1.3 Higher owner education level increases the odds of LOB survival.

\section{Business characteristics}

H2.1 Longer time in operation increases the odds of LOB survival.

H2.2 Larger business size increases the odds of survival.

H2.3 Operation in a low-barrier industry decreases the odds of LOB survival.

\section{Regional characteristics}

H3.1 Location in a more highly educated place increases the odds of LOB survival.

H3.2 Higher population density increases the odds of LOB survival.

H3.3 Higher unemployment increases the odds of LOB survival (recession-push). 


\section{DATA}

We merge three limited-access Census Bureau data sets by individual firm and establishment level to investigate the effect of factors on LOB location and survival. The three databases are the Integrated Longitudinal Business Database (ILBD, approximately 18 million establishments annually), the Longitudinal Business Database (LBD, approximately 8 million establishments annually) and the Survey of Business Owners (SBO, approximately 2.3 million establishments in 2002). The SBO is not a longitudinal survey of businesses, but becomes the base of our sample because only it contains the owner socioeconomic variables of interest. Then, by linking the SBO with the LBD and the ILBD by firm ID number, one can trace longitudinal changes of the matched businesses. ${ }^{4}$ After dropping non-LOB and incomplete observations within the $2002 \mathrm{SBO}$, and merging in the LBD and ILBD, the final sample contains about ${ }^{5} 127,000$ LOB observations. Thus, this final sample derives from the 2002 SBO, and then tracks those businesses' survival 2002-2006 using the ILBD/LBD. Before dropping non-LOB businesses from the SBO for this research, LOB comprised about 5 percent of complete SBO responses, with Asian-owned business at 4 percent, Black-owned businesses 3 percent, and White-owned businesses 88 percent, so this sample size is expected.

While measures of business ownership are available from the SBO, the data are crosssectional and cannot capture the survival dynamics of LOBs. Such measures are available from the LBD and ILBD. On the other hand, the LBD and ILBD lack information on the characteristics of business owners such as race, ethnicity ${ }^{6}$, gender, education level, whether the owner is foreign born, and access to capital. Such information is available from the SBO. The appendix contains a table detailing the FSRDC datasets under consideration. We include all Latino-owned businesses present in the data, irrespective of whether the owner is U.S. or foreign born. ${ }^{7}$

The ILBD consists of administrative records for all non-employer business units, and is necessary to address the issue that, while SBO has information about firms that have no paid employees, the LBD has information only about establishments with paid employees. The SBO occurs in years ending in 2 and 7 . Based on a special project to improve Census Bureau data, the Census Bureau granted access to the authors for these datasets between 2002 and 2007 and hence, this paper tracks establishments over that period. Although location of the businesses is available from these merged data sets, location specific characteristics such as agglomeration, racial make-up of the location, amenities, and market size are not available in this data and have been found to be significant in the past. Thus, we include numerous county-level variables in our specification with the goal of controlling for labor market and

\footnotetext{
${ }^{4}$ Access to these three micro-datasets is limited. Qualified researchers with approved FSRDC projects gain restricted access. In the analysis that follows, XX indicates that the value, sign, and significance of certain estimated coefficients are non-disclosed to protect confidentiality of individuals and businesses under Census guidelines. Note that this connection implies that business owner characteristics are at the firm level.

${ }^{5}$ Census disclosure review prevents the disclosure of the exact number of observations, so we round to the nearest 1,000 and use sample percentages.

${ }^{6}$ Although an imperfect measure of the more complex reality of ethnicity in the U.S., we define a business as Latino-owned if the majority shareholder of the firm responded that they are Hispanic.

${ }^{7}$ Unfortunately, the 2002 SBO does not contain a control for foreign-born status. This is an important area for future research.
}

(c) Southern Regional Science Association 2019. 
regional economic performance trends. This requires linking merged data with location specific factors that are publicly available from the Bureau of the Census, the BEA and the USDA.

The merged 2002 SBO with the 2002-2007 ILBD, LBD, and public county-level data creates a panel of LOB from 2002-2007 with individual business specific business-owner, business, and regional characteristics. The rounded sample sizes in (thousands) each year 2002 to 2006 are 33, 28, 26, 24, and 22. The Census Bureau disclosure prevention process limits the ability to use descriptive statistics to introduce all of the data, including descriptive survival numbers by race. Despite this limitation, we are allowed to include descriptive statistics in Tables 1, 2, and 3. For example, the percent of the sample that is Mexican, Cuban, Puerto Rican, and other Hispanic (born or by ancestry) is 42, 13, 7, and 38 , respectively.

\section{METHODS}

The empirical approach to test these hypotheses is grounded in the theory of firm entry, growth and exit, which is well-developed in the small business and industrial organization literature (Evans, 1987; Dunne et al., 1989; Evans and Leighton, 1989). We draw on this literature to motivate the exit ${ }^{8}$ behavior of LOB. A generalized version of this framework models LOB activity or outcomes as a function of explanatory factors as well as stochastic variables as follows:

$$
y_{i t}=f\left(\mathbf{x}_{i t}, \mathbf{z}_{i t}, \mathbf{l}_{i t}, \varepsilon_{i t}\right)
$$

where $y_{i t}$ is the LOB outcome variable at time $t$ for establishment $i, \mathbf{x}$ is a vector of business owner variables, $\mathbf{z}$ is a vector of business characteristics, and $\mathbf{l}$ is a vector of business location variables that affect the outcome. $\varepsilon_{i t}$ is a random error term. This approach captures business exit behavior, and allows incorporation of business, business owner, and regionspecific factors. $^{9}$ The main LOB outcome in the analysis is the probability of LOB yearover-year survival. The explanatory variables representing personal traits refer to the traits of the owner or majority shareholder of the firm, ${ }^{10}$ while regional factors include information about the county in which the business is located.

This article uses duration analysis employing the hazard model to investigate the determinants of firm survival. This framework allows us to quantify the timing of the exit, rather than the mere incidence. The application of a hazard model (Cox, 1972, 1975) for likelihood

\footnotetext{
${ }^{8}$ We are unable to track nascent entrepreneurs in our dataset, so we examine the exit rather than entry decision. The data also does not contain the cause of exit, but the comprehensive nature of the LBD does allow us to know that a firm "exit" is permanent, and not a transitory discontinuing of operations.

${ }^{9}$ An alternative technique to using numerous indicator variables in the model is to run the model separately for variables of particular interest, such as Latina entrepreneurs and various industries. Using an indicator variable presumes that differences between groups can be represented by a change in the intercept, but it is likely that there are behavioral (slope) differences as well. Running the models separately could shed light on important behavioral differences particularly those that affect survivability. Unfortunately, running the models separately would produce too many implicit samples and such regressions would not pass the non-disclosure requirements of the U.S. Census Bureau.

${ }^{10}$ If individuals share ownership of a firm equally, we randomly assign ownership to one owner. The results are robust to the inclusion of an indicator for multiple owners.
}

(c)Southern Regional Science Association 2019. 
Table 1: Business Owner Variable Summary Statistics

\begin{tabular}{|c|c|c|c|}
\hline Business Owner Variables & Mean & Std. Dev. & Source \\
\hline Woman & 0.190 & 0.392 & SBO \\
\hline Primary source of income & 0.612 & 0.487 & $\mathrm{SBO}$ \\
\hline Owner ancestry (base: other Hispanic) & & & $\mathrm{SBO}$ \\
\hline Mexican & 0.418 & 0.493 & \\
\hline Cuban & 0.135 & 0.341 & \\
\hline Puerto Rican & 0.066 & 0.249 & \\
\hline Other Hispanic & 0.382 & 0.486 & \\
\hline Owner education (base: $<H S$ ) & & & $\mathrm{SBO}$ \\
\hline Less than high school & 0.081 & 0.273 & \\
\hline High school & .0181 & 0.385 & \\
\hline Some college & 0.142 & 0.349 & \\
\hline Tech or trade school & 0.047 & 0.211 & \\
\hline Associate degree & 0.037 & 0.188 & \\
\hline Bachelor's degree & 0.153 & 0.360 & \\
\hline Graduate degree & 0.137 & 0.344 & \\
\hline Primary duties (multiple response) & & & $\mathrm{SBO}$ \\
\hline Produce goods/services & 0.354 & 0.478 & \\
\hline Management & 0.542 & 0.498 & \\
\hline Finances & 0.435 & 0.496 & \\
\hline Other function & 0.273 & 0.446 & \\
\hline Weekly hours (base: less than 20) & & & $\mathrm{SBO}$ \\
\hline Zero & 0.023 & 0.150 & \\
\hline Less than 20 & 0.087 & 0.079 & \\
\hline 20 to 39 & 0.083 & 0.276 & \\
\hline 40 & 0.131 & 0.337 & \\
\hline 41 to 59 & 0.274 & 0.446 & \\
\hline Greater than 59 & 0.201 & 0.400 & \\
\hline Owner age (base: less than 25) & & & $\mathrm{SBO}$ \\
\hline Less than 25 & 0.004 & 0.059 & \\
\hline 25 to 34 & 0.075 & 0.263 & \\
\hline 35 to 44 & 0.235 & 0.424 & \\
\hline 45 to 54 & 0.239 & 0.426 & \\
\hline 55 to 64 & 0.155 & 0.362 & \\
\hline Older than 64 & 0.069 & 0.253 & \\
\hline
\end{tabular}

(C)Southern Regional Science Association 2019. 
Table 2: Business Variable Summary Statistics

\begin{tabular}{|c|c|c|c|}
\hline Business Variables & Mean & Std. Dev. & Source \\
\hline Business age & XX & XX & LBD \\
\hline Multiple establishments & 0.165 & 0.371 & ILBD/LBD \\
\hline Start-up capital source (base: savings) & & & $\mathrm{SBO}$ \\
\hline Savings & 0.563 & 0.469 & \\
\hline Assets & 0.119 & 0.324 & \\
\hline Credit & 0.091 & 0.287 & \\
\hline Government loan or guarantee & 0.025 & 0.156 & \\
\hline Bank loan & 0.146 & 0.353 & \\
\hline Venture Capital & 0.033 & 0.178 & \\
\hline None needed & 0.058 & 0.234 & \\
\hline Other & 0.235 & 0.424 & \\
\hline Customer type (>10\% of sales) & & & $\mathrm{SBO}$ \\
\hline Federal government & 0.052 & 0.221 & \\
\hline State or local government & 0.078 & 0.268 & \\
\hline Other Businesses & 0.279 & 0.448 & \\
\hline Individuals & 0.385 & 0.487 & \\
\hline NAICS industry (base: NAICS 11) & & & LBD/ILBD \\
\hline 11: Ag., Forestry, Fishing \& Hunting & 0.006 & 0.078 & \\
\hline 21: Mining, Quarrying, Oil \& Gas & 0.003 & 0.051 & \\
\hline 22: Utilities & 0.000 & 0.017 & \\
\hline 23: Construction & 0.113 & 0.316 & \\
\hline 31-33: Manufacturing & 0.076 & 0.265 & \\
\hline 42: Wholesale Trade & 0.061 & 0.239 & \\
\hline 44-45: Retail Trade & 0.153 & 0.360 & \\
\hline 48-49: Transportation \& Warehousing & 0.047 & 0.211 & \\
\hline 51: Information & 0.016 & 0.125 & \\
\hline 52: Finance and Insurance & 0.043 & 0.204 & \\
\hline 53: Real Estate, Rental \& Leasing & 0.024 & 0.154 & \\
\hline 54: Prof., Scientific, \& Tech. Service & 0.116 & 0.321 & \\
\hline 55: Management of Companies & 0.005 & 0.069 & \\
\hline 56: Admin. \& Waste Mng. Services & 0.059 & 0.237 & \\
\hline 61: Educational Services & 0.012 & 0.110 & \\
\hline 62: Health Care \& Social Assistance & 0.081 & 0.273 & \\
\hline 71: Arts, Entertainment, \& Recreation & 0.010 & 0.101 & \\
\hline 72: Accommodation and Food Services & 0.104 & 0.305 & \\
\hline 81: Other Services & 0.070 & 0.256 & \\
\hline
\end{tabular}

Note: Access to these three micro-datasets is limited. Qualified researchers with approved FSRDC projects gain restricted access. In the analysis that follows, XX indicates that the value, sign, and significance of certain estimated coefficients are non-disclosed to protect confidentiality of individuals and businesses under Census guidelines. Note that this connection implies that business owner characteristics are at the firm level.

(C)Southern Regional Science Association 2019. 
Table 3: Regional Variable Summary Statistics

\begin{tabular}{lccc}
\hline \hline Regional (County-Level) Variables & Mean & Std. Dev. & Source \\
\hline \% of population with education: & XX & XX & Census/ACS \\
High school & 26.08 & XX & Census/ACS \\
Some college & 19.85 & XX & Census/ACS \\
Associate degree & 6.79 & XX & Census/ACS \\
Bachelor's degree & 17.71 & XX & Census/ACS \\
Graduate degree & 10.69 & XX & BEA \\
Per capita income & $23,609.29$ & XX & BEA \\
Unemployment rate & 5.65 & XX & BEA \\
Labor force participation rate & 70.95 & XX & BEA \\
Rural-urban continuum code & & & USDA \\
1: metro area, $\geq 1$ millionpop. & 0.671 & 0.470 & \\
2: metro area, 0.25 to 1 million pop. & 0.175 & 0.380 & \\
3: metro area, $<250,000$ & 0.072 & 0.258 & \\
4: adjacent to metro, $\geq 20,000$ & 0.028 & 0.165 & \\
5: not adjacent to metro, $\geq 20,000$ & 0.012 & 0.109 & \\
6: adjacent to metro, $2,500-19,999$ & 0.023 & 0.151 & \\
7: not adjacent to metro, $2,500-19,999$ & 0.016 & 0.125 & \\
8: adjacent to a metro, $<2,500$ & 0.002 & 0.039 & \\
9: not adjacent to a metro, $<2,500$ & 0.003 & 0.050 & Census \\
Number of building permits issued & XX & XX & \\
\hline
\end{tabular}

Note: Access to these three micro-datasets is limited. Qualified researchers with approved FSRDC projects gain restricted access. In the analysis that follows, XX indicates that the value, sign, and significance of certain estimated coefficients are non-disclosed to protect confidentiality of individuals and businesses under Census guidelines. Note that this connection implies that business owner characteristics are at the firm level.

of firm survival has become a routine method for survival data used in the empirical literature since Audretsch and Mahmood (1995). See Christie and Sjoquist (2012) and Cauchie and Vaillant (2016) for recent applications. The probability that this firm does not survive within a short interval of time, $(t, t+d t)$, conditional on the fact that it has survived as of period t can be calculated as follows:

$$
\mathbf{h}_{i}\left(t \mid \mathbf{x}_{i}, \mathbf{z}_{i}, \mathbf{l}_{i}\right)=\lim _{d t \rightarrow 0} \frac{P\left(t \leq T \leq t+d t \mid T \geq t ; x_{i}, z_{i}, l_{i}\right)}{d t}
$$

where $\mathbf{x}, \mathbf{z}$, and $\mathbf{l}$ are vectors of covariates likely to affect the duration of the firm. Empirically, to examine the effects of the covariates on the duration, the proportional hazards model (Cox, 1972 ) assumes the hazard rate is a multiplicative function of a baseline hazard, $h_{0}(\mathrm{t})$, and an exponential function of a set of covariates:

$$
\mathbf{h}_{i}\left(t \mid \mathbf{x}_{i}, \mathbf{z}_{i}, \mathbf{l}_{i}\right)=h_{0}(t) \exp \left(\mathbf{x}_{i} \beta+\mathbf{z}_{i} \gamma+\mathbf{l}_{i} \delta\right)
$$

where $\beta, \gamma$, and $\delta$ are vectors of coefficients on business owner, business, and business location explanatory variables, respectively.

(C)Southern Regional Science Association 2019. 
The probability of survival is assumed to depend on the same set of explanatory factors used in equation 2. Since there is little theoretical support for any particular parametric shape of the baseline hazard, most studies use a nonparametric approach (Christie and Sjoquist, 2012) for estimation. Therefore, we use a nonparametric approach, but also use parametric models as a robustness check. ${ }^{11}$

\section{RESULTS}

Past studies of ethnic associations rely on studies on the determinants of business survival for interpretation of economic and social significance. While Latinos are more likely to work in sectors such as the services (Robles and Cordero-Guzman, 2007; Puryear et al., 2008), construction, wholesale trade, and retail trade sectors (U.S. Census Bureau, 2010), understanding the significance of these descriptive statistics requires interpreting the extent to which those sectors are also relatively vulnerable to failure. To facilitate such a study, this article again divides our discussion into the three topic areas under examination and presents the main results in Tables 2.1-2.3. Although the estimates presented in each table result from single regressions (three estimation techniques: Cox, Exponential, and Weibull), we separate the tables to facilitate the results discussion into three categories: business owner, business, and regional characteristics.

Due to space limitations, we omit reporting certain controls and Census-suppressed estimates. The omitted establishment-level control variables include business organization type indicators (coop, estate, non-profit, public, husband and wife), establishment employment, establishment payroll, firm employment, firm payroll, state industry employment, state indicators variables, and NAICS sectors 22 (suppressed), 51 (suppressed), and 52 (suppressed). The omitted county-level control variables include population, population squared, population density, age 25 to 34 population, age 35 to 44 population, age 45 to 54 population, age 55 to 64 population, age greater than 64 population, female population, female population squared, Black population, Black population squared, Asian population, Asian population squared, Hispanic population, Hispanic population squared, number of build permits issued, industry employment, and USDA ERS Natural Amenities Scale (suppressed). The variance inflation factors indicate that collinearity is not a concern. Except for Census-suppressed estimates (noted below), full results are available in Carpenter (2016) and upon request.

The hazard function provides the risk of non-survival; that is, the probability that a business will not still be in business in the next year, on the condition that this business has survived up to the beginning of the current year (Christie and Sjoquist, 2012). We focus on the results given by the Cox proportional hazard model, but also include two parametric models - exponential and Weibull - to check the sensitivity of the results with respect to assumed distribution. ${ }^{12}$ Tables 4, 5, and 6 contain the results of these three models and shows that the results are stable across model selection. For ease of comparison, these results are presented as odds ratios, where a value higher than 1.00 implies an inverse relationship with survival.

\footnotetext{
${ }^{11}$ We also note that the results are robust to mixed effects survival models.

${ }^{12}$ We include these specific parametric models to allow for odds ratio comparisons. The results are generally robust when using other parametric models.
}

(C)Southern Regional Science Association 2019. 
Table 4: Business Owner Characteristics: Survival Model Results

\begin{tabular}{|c|c|c|c|}
\hline Business Owner Variables & Cox Prop Hazard & Exponential & $\overline{\text { Weibull }}$ \\
\hline Female & $\begin{array}{c}1.06^{* * *} \\
(0.02)\end{array}$ & $\begin{array}{c}1.06^{* * *} \\
0.02)\end{array}$ & $\begin{array}{c}1.06^{* * *} \\
0.02)\end{array}$ \\
\hline Primary source of income & $\begin{array}{c}0.85^{* * *} \\
(0.02)\end{array}$ & $\begin{array}{c}0.84^{* * *} \\
0.02)\end{array}$ & $\begin{array}{c}0.82^{* * * *} \\
0.02)\end{array}$ \\
\hline Mexican & $\begin{array}{c}1.02 \\
(0.03)\end{array}$ & $\begin{array}{c}1.02 \\
(0.03)\end{array}$ & $\begin{array}{c}1.02 \\
(0.03)\end{array}$ \\
\hline Cuban & $\begin{array}{c}1.00 \\
(0.04)\end{array}$ & $\begin{array}{c}0.99 \\
(0.04)\end{array}$ & $\begin{array}{c}0.98 \\
(0.04)\end{array}$ \\
\hline Puerto Rican & $\begin{array}{c}1.19^{* * *} \\
(0.05)\end{array}$ & $\begin{array}{c}1.20^{* * *} \\
(0.05)\end{array}$ & $\begin{array}{c}1.22^{* * * *} \\
(0.05)\end{array}$ \\
\hline Owner education: High school & $\begin{array}{c}0.99 \\
(0.04)\end{array}$ & $\begin{array}{l}1.00 \\
(0.04)\end{array}$ & $\begin{array}{c}1.01 \\
(0.04)\end{array}$ \\
\hline Owner education: Some college & $\begin{array}{l}1.00 \\
(0.04)\end{array}$ & $\begin{array}{l}1.00 \\
(0.04)\end{array}$ & $\begin{array}{l}1.02 \\
(0.04)\end{array}$ \\
\hline Owner education: Tech or trade school & $\begin{array}{c}0.96 \\
(0.05)\end{array}$ & $\begin{array}{c}0.96 \\
(0.05)\end{array}$ & $\begin{array}{c}0.97 \\
(0.05)\end{array}$ \\
\hline Owner education: Associate degree & $\begin{array}{c}0.98 \\
(0.06)\end{array}$ & $\begin{array}{c}0.99 \\
(0.06)\end{array}$ & $\begin{array}{c}1.00 \\
(0.06)\end{array}$ \\
\hline Owner education: Bachelor's degree & $\begin{array}{c}1.01 \\
(0.04)\end{array}$ & $\begin{array}{c}1.01 \\
(0.04)\end{array}$ & $\begin{array}{c}1.03 \\
(0.04)\end{array}$ \\
\hline Owner education: Graduate degree & $\begin{array}{c}0.96 \\
(0.04)\end{array}$ & $\begin{array}{c}0.97 \\
(0.04)\end{array}$ & $\begin{array}{c}1.00 \\
(0.05)\end{array}$ \\
\hline Primary duties Produce goods/services & $\begin{array}{c}1.04 \\
(0.03)\end{array}$ & $\begin{array}{c}1.04 \\
(0.03)\end{array}$ & $\begin{array}{l}1.05^{*} \\
(0.03)\end{array}$ \\
\hline Primary duties Management & $\begin{array}{l}1.03 \\
(0.03)\end{array}$ & $\begin{array}{c}1.02 \\
(0.03)\end{array}$ & $\begin{array}{c}1.02 \\
(0.03)\end{array}$ \\
\hline Primary duties Finances & $\begin{array}{c}0.94^{* *} \\
(0.02)\end{array}$ & $\begin{array}{l}0.94^{* *} \\
(0.02)\end{array}$ & $\begin{array}{c}0.94^{* *} \\
(0.02)\end{array}$ \\
\hline Weekly hours 20 to 39 & $\begin{array}{c}0.94 \\
(0.04)\end{array}$ & $\begin{array}{c}0.95 \\
(0.04)\end{array}$ & $\begin{array}{c}0.97 \\
(0.05)\end{array}$ \\
\hline Weekly hours 40 & $\begin{array}{c}0.95 \\
(0.04)\end{array}$ & $\begin{array}{c}0.96 \\
(0.04)\end{array}$ & $\begin{array}{c}0.98 \\
(0.04)\end{array}$ \\
\hline Weekly hours 41 to 59 & $\begin{array}{c}0.86^{* * *} \\
(0.04)\end{array}$ & $\begin{array}{c}0.86^{* * *} \\
(0.04)\end{array}$ & $\begin{array}{c}0.87^{* * * *} \\
(0.04)\end{array}$ \\
\hline Weekly hours More than 59 & $\begin{array}{c}0.89^{* *} \\
(0.04)\end{array}$ & $\begin{array}{c}0.90^{* *} \\
(0.04)\end{array}$ & $\begin{array}{l}0.92^{*} \\
(0.04)\end{array}$ \\
\hline Owner Age 25 to 34 & $\begin{array}{l}0.89^{*} \\
(0.06)\end{array}$ & $\begin{array}{c}0.91 \\
(0.06)\end{array}$ & $\begin{array}{c}0.95 \\
(0.06)\end{array}$ \\
\hline Owner Age 35 to 44 & $\begin{array}{c}0.81^{* * *} \\
(0.05)\end{array}$ & $\begin{array}{c}0.81^{* * *} \\
(0.05)\end{array}$ & $\begin{array}{c}0.79^{* * * *} \\
(0.05)\end{array}$ \\
\hline Owner Age 45 to 54 & $\begin{array}{c}0.82^{* * *} \\
(0.05)\end{array}$ & $\begin{array}{c}0.81^{* * *} \\
(0.05)\end{array}$ & $\begin{array}{c}0.78^{* * * *} \\
(0.05)\end{array}$ \\
\hline Owner Age 55 to 64 & $\begin{array}{c}0.89^{* *} \\
(0.05)\end{array}$ & $\begin{array}{c}0.89^{* *} \\
(0.05)\end{array}$ & $\begin{array}{c}0.87^{* *} \\
(0.05)\end{array}$ \\
\hline Owner Age Older than 64 & $\begin{array}{c}0.95 \\
(0.06)\end{array}$ & $\begin{array}{c}0.96 \\
(0.06)\end{array}$ & $\begin{array}{c}1.00 \\
(0.06)\end{array}$ \\
\hline
\end{tabular}

(C)Southern Regional Science Association 2019. 


\subsection{Business-owner Characteristics}

The results presented in Table 4 support the previously found result for entrepreneurs in general (rather than LOB in particular) that younger entrepreneurs have lower business survival rates (Lin et al., 2000; Van Praag, 2003; Fairlie, 2005). The results presented in Table 4 support our first hypothesis (H1.1) and show that older Latino business owners are more likely to stay in business. Specifically, relative to business owners under the age of 25, the age groups of 25 to 34,35 to 44,45 to 54, and 55 to 64 are about 12 percent, 23 percent, 22 percent, and 12 percent respectively more likely to survive. Of course, age is correlated with experience and it is likely that, despite the extensive control variables, experience and related aspects of business ownership remain uncontrolled for in the error term. The estimation did not produce a statistically significant impact of any education level on LOB survival and thus we fail to find support for our third hypothesis (H1.3). The results that education does not have a statistically significant impact on firm survival is consistent with past results (Taylor, 1999; Dahl and Reichstein, 2007; Georgellis et al., 2007; Asoni and Sanandaji, 2016). Similar to arguments made in Asoni and Sanandaji (2016), it may be that the inclusion of significant controls leads to the contradiction of studies that report a positive association between education and business survival (Ganotakis, 2012; Millán et al., 2012; Oberschachtsiek, 2012; Lechmann and Schnabel, 2014). On the other hand, it may be that owners who lack education tend to maintain a standard small-scale business model, providing much if not all of the firm's labor themselves and do not attempt expansion. As expected, both working more than 40 hours per week and having the business be the owner's primary source of income increase the odds of survival.

This article also shows that the shorter-than-male owned business lifespan commonly found for female business owners in other populations (Lin et al., 2000; Nziramasanga and Lee, 2001; Georgellis et al., 2007; Fairlie and Robb, 2009; Haapanen and Tervo, 2009) is also applicable to Latinas. Further, our results (based on the 2002 Survey of Business Owners) represent evidence that this difference across gender found in Fairlie and Robb (2009), which was based on the 1992 Characteristics of Business Owners survey, continues to exist a decade later. Thus, we find support for our second hypothesis (H1.2) that Latina-owned businesses are less likely to survive than Latino-owned businesses. Consistent with Rosenthal and Strange (2012)'s more general finding, it may be that Latina business owners are less networked than their male counterparts, and thus derive less benefit from agglomeration and are less likely to survive. Similarly, they may also have greater domestic burdens leading to lower ability to commute.

An advantage of the access to such a large dataset is the ability to examine numerous interactions among the control variables. We tested many interactions, but most are insignificant and the FSRDC has not approved release of the estimates. However, we can report the signs of these results. The only practically and statistically significant interaction result was the effect of interacting the female business owner indicator variable with others. If the business is a primary source of income, it disproportionately affects female business owners and increases the probability of staying in business. It may be that part time female business owners are subject to more family pressures or similar obstacles, which contributes to their higher likelihood of exit.

(C)Southern Regional Science Association 2019. 
Another advantage of access to such a large dataset is the ability to examine specific Latino subgroups. The subgroup detail available in the SBO was on whether the Latino business owner has Mexican, Cuban, Puerto Rican, or other Hispanic ancestry. The only ancestral origin that was significant is Puerto Rican origin. Note that this article uses data on the continental 48 states and Washington D.C., and excludes businesses in Puerto Rico. On average, having Puerto Rican ancestry decreases the odds of business survival by 19 percent, relative to other omitted Hispanic ethnicities. These results provide empirical evidence to support recent discussions of the low barriers to entry in the U.S. for Puerto Rican migrants and the accompanying struggles (Abel and Deitz, 2014), and is consistent with evidence that out-migrants from Puerto Rico are relatively low-skill (Borjas, 2008).

Puerto Rican migrants' experience in the continental U.S. is significantly different from that of Cuban immigrants. Cuban immigration to the U.S. increased substantially after the 1959 revolution, but continued through the 1990s. It is still true that compared to the overall immigrant and U.S.-born populations, Cubans are less likely to be proficient in English, have lower educational attainment, and earn a lower household income (Rusin and Batalova, 2015). It is also true, however, that Cuban immigrants, are older, and have a higher level education and income than the rest of the Hispanic population in the U.S. (Center, 2006). Despite these differences, the impact of the LOB being Cuban-owned on survival rates is statistically insignificant.

\subsection{Business Characteristics}

The results presented in Table 5 fail to support our fourth hypothesis (H2.1) that business age has a positive impact on the probability of survival. It may be that our variable "business age" does not adequately account for nonlinearities in the impact of business age on survival, which have been shown to be significant (Fackler et al., 2013). While adding a squared term did not affect statistical significance, alternative specifications that include indicator variables for a business being older or younger than three years do indicate that younger businesses are more likely to exit. Although we hypothesized that larger businesses may be more established and thus have a higher likelihood of survival, and the coefficients on firm employment and establishment employment are statistically significant, the coefficients are both estimated as 1.00. Hence, this article does not find significant support for the fifth hypothesis (H2.2) that larger business size increases the odds of survival.

The only start-up capital source that has a statistically significant impact relative to the omitted category is personal savings (increases odds). For expansion capital source, using personal savings decreases the odds of survival, while using a bank loan increases the odds of survival. This bank loan effect may be due to selection, business planning that takes place during the approval process, or lower interest. As noted in the literature review, using personal capital for investment is rare among LOB (relative to White-owned businesses), so the ability to use personal savings likely correlates with personal wealth and other factors that increase survival odds.

In the $2002 \mathrm{SBO}$, the customer type question was multiple response. That is, the survey asked respondents to mark all of the customer types that represented at least 10 percent of their total sales. Both having individuals, other businesses, and local or state government 
account for more than 10 percent of their sales increases the odds of survival. Individuals had the largest effects. If the federal government, conversely, accounts for more than 10 percent of sales, odds of survival decrease. The contrasting results for engagement in state versus federal contracting are unexpected. It is possible that the federal contracting system somehow puts LOB at risk (e.g., slow payment), or perhaps that businesses are formed with a goal of obtaining a particular federal contract, then dissolved when that contract is no longer necessary.

Table 5: Business Characteristics: Survival Model Results

\begin{tabular}{|c|c|c|c|}
\hline Business Owner Variables & Cox & Exponential & Weibull \\
\hline Start-up capital source: Savings & $\begin{array}{l}0.94^{* *} \\
(0.03)\end{array}$ & $\begin{array}{c}0.94^{* *} \\
(0.03)\end{array}$ & $\begin{array}{c}0.93^{* *} \\
(0.03)\end{array}$ \\
\hline Start-up capital source: Assets & $\begin{array}{c}1.00 \\
(0.03)\end{array}$ & $\begin{array}{c}1.00 \\
(0.03)\end{array}$ & $\begin{array}{c}1.00 \\
(0.03)\end{array}$ \\
\hline Start-up capital source: Credit & $\begin{array}{c}0.94 \\
(0.04)\end{array}$ & $\begin{array}{c}0.95 \\
(0.04)\end{array}$ & $\begin{array}{c}0.96 \\
(0.04)\end{array}$ \\
\hline Start-up capital source: Government loan & $\begin{array}{c}0.98 \\
(0.07)\end{array}$ & $\begin{array}{c}0.98 \\
(0.07)\end{array}$ & $\begin{array}{c}0.99 \\
(0.07)\end{array}$ \\
\hline Start-up capital source: Bank loan & $\begin{array}{c}0.99 \\
(0.03)\end{array}$ & $\begin{array}{c}0.99 \\
(0.03)\end{array}$ & $\begin{array}{c}1.00 \\
(0.03)\end{array}$ \\
\hline Start-up capital source: Venture capital & $\begin{array}{c}1.04 \\
(0.06)\end{array}$ & $\begin{array}{c}1.04 \\
(0.06)\end{array}$ & $\begin{array}{c}1.05 \\
(0.06)\end{array}$ \\
\hline Start-up capital source: None needed & $\begin{array}{c}1.06 \\
(0.05)\end{array}$ & $\begin{array}{c}1.07 \\
(0.05)\end{array}$ & $\begin{array}{l}1.09^{*} \\
(0.05)\end{array}$ \\
\hline Expansion capital source: Savings & $\begin{array}{c}1.10^{* * *} \\
(0.04)\end{array}$ & $\begin{array}{c}1.11^{* * *} \\
(0.04)\end{array}$ & $\begin{array}{c}1.13^{* * *} \\
(0.04)\end{array}$ \\
\hline Expansion capital source: Assets & $\begin{array}{c}1.06 \\
(0.05)\end{array}$ & $\begin{array}{c}1.07 \\
(0.05)\end{array}$ & $\begin{array}{l}1.09^{*} \\
(0.05)\end{array}$ \\
\hline Expansion capital source: Credit & $\begin{array}{l}1.06 \\
(0.04)\end{array}$ & $\begin{array}{l}1.05 \\
(0.04)\end{array}$ & $\begin{array}{l}1.05 \\
(0.04)\end{array}$ \\
\hline Expansion capital source: Government loan & $\begin{array}{c}1.00 \\
(0.08)\end{array}$ & $\begin{array}{c}0.99 \\
(0.08)\end{array}$ & $\begin{array}{c}0.99 \\
(0.08)\end{array}$ \\
\hline Expansion capital source: Bank loan & $\begin{array}{c}0.81^{* * *} \\
(0.03)\end{array}$ & $\begin{array}{c}0.80^{* * *} \\
(0.03)\end{array}$ & $\begin{array}{c}0.78^{* * *} \\
(0.03)\end{array}$ \\
\hline Expansion capital source: Venture capital & $\begin{array}{c}1.09 \\
(0.08)\end{array}$ & $\begin{array}{c}1.10 \\
(0.08)\end{array}$ & $\begin{array}{c}1.13 \\
(0.09)\end{array}$ \\
\hline Expansion capital source: None needed & $\begin{array}{c}0.96 \\
(0.03)\end{array}$ & $\begin{array}{c}0.96 \\
(0.03)\end{array}$ & $\begin{array}{c}0.96 \\
(0.04)\end{array}$ \\
\hline 10 percent of sales to: Federal government & $\begin{array}{l}1.10^{*} \\
(0.06)\end{array}$ & $\begin{array}{l}1.10^{*} \\
(0.06)\end{array}$ & $\begin{array}{l}1.10^{*} \\
(0.06)\end{array}$ \\
\hline 10 percent of sales to: State or local government & $\begin{array}{c}0.84^{* * *} \\
(0.04)\end{array}$ & $\begin{array}{c}0.84^{* * *} \\
(0.04)\end{array}$ & $\begin{array}{c}0.84^{* * *} \\
(0.04)\end{array}$ \\
\hline 10 percent of sales to: Other businesses & $\begin{array}{c}0.93^{* * *} \\
(0.02)\end{array}$ & $\begin{array}{c}0.93^{* * *} \\
(0.02)\end{array}$ & $\begin{array}{c}0.93^{* * *} \\
(0.02)\end{array}$ \\
\hline
\end{tabular}

(C)Southern Regional Science Association 2019. 
Table 5 - Continued from previous page

\begin{tabular}{|c|c|c|c|}
\hline Business Owner Variables & Cox & Exponential & Weibull \\
\hline 10 percent of sales to: Individuals & $\begin{array}{c}0.85^{* * * *} \\
(0.02)\end{array}$ & $\begin{array}{c}0.85^{* * *} \\
(0.02)\end{array}$ & $\begin{array}{c}0.85^{* * *} \\
(0.02)\end{array}$ \\
\hline 10 percent of sales to: Business Age & $\begin{array}{c}1.02 \\
(0.02)\end{array}$ & $\begin{array}{c}0.99 * * * \\
(0.00)\end{array}$ & $\begin{array}{c}0.91^{* * *} \\
(0.00)\end{array}$ \\
\hline 10 percent of sales to: Multiple establishments & $\begin{array}{c}0.75^{* * * *} \\
(0.03)\end{array}$ & $\begin{array}{c}0.75^{* * *} \\
(0.03)\end{array}$ & $\begin{array}{c}0.75^{* * *} \\
(0.03)\end{array}$ \\
\hline NAICS 21: Mining, Quarrying, Oil \& Gas & $\begin{array}{c}0.97 \\
(0.21)\end{array}$ & $\begin{array}{c}1.00 \\
(0.22)\end{array}$ & $\begin{array}{c}1.11 \\
(0.25)\end{array}$ \\
\hline NAICS 23: Construction & $\begin{array}{c}0.92 \\
(0.10)\end{array}$ & $\begin{array}{c}0.95 \\
(0.10)\end{array}$ & $\begin{array}{c}1.04 \\
(0.10)\end{array}$ \\
\hline NAICS 31-33: Manufacturing & $\begin{array}{c}0.92 \\
(0.10)\end{array}$ & $\begin{array}{c}0.94 \\
(0.10)\end{array}$ & $\begin{array}{c}0.99 \\
(0.11)\end{array}$ \\
\hline NAICS 42: Wholesale Trade & $\begin{array}{l}0.82^{*} \\
(0.09)\end{array}$ & $\begin{array}{c}0.84 \\
(0.09)\end{array}$ & $\begin{array}{c}0.90 \\
(0.10)\end{array}$ \\
\hline NAICS 44-45: Retail Trade & $\begin{array}{c}0.94 \\
(0.10)\end{array}$ & $\begin{array}{c}0.97 \\
(0.11)\end{array}$ & $\begin{array}{c}1.04 \\
(0.12)\end{array}$ \\
\hline NAICS 48-49: Transportation \& Warehousing & $\begin{array}{c}0.95 \\
(0.10)\end{array}$ & $\begin{array}{c}0.97 \\
(0.11)\end{array}$ & $\begin{array}{c}1.04 \\
(0.12)\end{array}$ \\
\hline NAICS 53: Real Estate, Rental \& Leasing & $\begin{array}{l}0.80^{*} \\
(0.09)\end{array}$ & $\begin{array}{l}0.82^{*} \\
(0.10)\end{array}$ & $\begin{array}{c}0.90 \\
(0.11)\end{array}$ \\
\hline NAICS 54: Professional, Scientific, \& Tech Service & $\begin{array}{c}0.85 \\
(0.09)\end{array}$ & $\begin{array}{c}0.86 \\
(0.09)\end{array}$ & $\begin{array}{c}0.90 \\
(0.10)\end{array}$ \\
\hline NAICS 55: Management of Companies \& Enterprise & $\begin{array}{c}1.09 \\
(0.19)\end{array}$ & $\begin{array}{c}1.11 \\
(0.20)\end{array}$ & $\begin{array}{c}1.16 \\
(0.21)\end{array}$ \\
\hline NAICS 56: Administrative Support & $\begin{array}{l}0.93 \\
(0.11)\end{array}$ & $\begin{array}{c}0.95 \\
(0.11)\end{array}$ & $\begin{array}{c}1.01 \\
(0.12)\end{array}$ \\
\hline NAICS 61: Educational Services & $\begin{array}{c}0.72^{* *} \\
(0.10)\end{array}$ & $\begin{array}{c}0.73^{* *} \\
(0.10)\end{array}$ & $\begin{array}{c}0.75^{* *} \\
(0.11)\end{array}$ \\
\hline NAICS 62: Health Care \& Social Assistance & $\begin{array}{c}0.69^{* * * *} \\
(0.08)\end{array}$ & $\begin{array}{c}0.71^{* * *} \\
(0.09)\end{array}$ & $\begin{array}{c}0.75^{* * *} \\
(0.09)\end{array}$ \\
\hline NAICS 71: Arts, Entertainment, \& Recreation & $\begin{array}{c}0.92 \\
(0.12)\end{array}$ & $\begin{array}{c}0.94 \\
(0.12)\end{array}$ & $\begin{array}{c}1.00 \\
(0.13)\end{array}$ \\
\hline NAICS 72: Accommodation \& Food Services & $\begin{array}{l}0.82^{*} \\
(0.09)\end{array}$ & $\begin{array}{c}0.84 \\
(0.09)\end{array}$ & $\begin{array}{c}0.89 \\
(0.09)\end{array}$ \\
\hline NAICS 81: Other Services & $\begin{array}{c}0.85 \\
(0.09)\end{array}$ & $\begin{array}{c}0.87 \\
(0.10)\end{array}$ & $\begin{array}{c}0.92 \\
(0.10)\end{array}$ \\
\hline
\end{tabular}

Although all other (unsuppressed) industries except Management of Companies and Enterprises increase the probability of survival over the omitted category, only (1) Wholesale Trade, (2) Real Estate and Rental and Leasing, (3) Education Services, and (4) Health Care and Social Assistance have statistically significant increase in the probability of survival in the Cox specification. Indeed, LOBs in the educational services and health care and social assistance industries were the most likely to survive and be significant across all specifica(C)Southern Regional Science Association 2019. 
tions. Bates et al. (2011) find that businesses within the low-barrier industries face a greater likelihood of going out of business compared to businesses within the high barrier industries. The analysis presented here shows that construction and food service do not have low survival rates relative to the omitted category, and thus we can reject our sixth hypothesis (H2.3), that LOB in low-barrier industries are less likely to survive. Unfortunately, the coefficient on the finance and insurance industry is suppressed in the survival analysis, so it is difficult to compare this article's results to prior work on high-barrier industries.

\subsection{Regional Characteristics}

One of the few statistically significant regional population factors is the percent of the county with some college but no degree as their highest educational attainment, which decreases the odds of LOB survival. Given that the model controls for owner education levels, it may be that an unobserved variable biases this coefficient. For example, it is possible that areas lacking a university may cause people to attempt online degrees, where the non-completion rate is higher than traditional classroom-based programs (Patterson and McFadden, 2009). As such, this variable may represent a proxy for a less-educated but aspiring population, in which case this finding is consistent with our seventh hypothesis (H3.1) and Millan et al. (2014), who find that a population's share of highly educated individuals has a positive impact on all measures of individual entrepreneurship performance due to both demand and supply-side factors. Our results thus not only support the finding that entrepreneurship promotion in the absence a more educated populace may be less effective in general, but also that reducing dropout rates in higher education institutions in particular may be important. Alternatively, a boom-bust economy might produce a high level of degree non-completions as people alternate between lack of tuition funds and remunerative full-time non-degree work. Thus, it may be that areas with many degree non-completers are relatively difficult for business survival for reasons only tangentially related to the regional populations education level.

This article does not find a significant effect of population density on the probability of survival. Thus, we fail to find support for H3.2. This article also does not find support for the final hypothesis under consideration, the recession-push hypothesis (H3.3) or the prosperity-pull hypothesis. Similarly, rurality does not appear to change survival probability of a LOB. ${ }^{13}$ Finally, we note that the results are robust to the exclusion of 2006, and various other parametric specifications, including gompertz, gamma, and log-log models.

\section{CONCLUSIONS}

This article uses restricted-access Federal microdata from roughly 127,000 businesses to address issues not explored in the literature on ethnic business survival in general, and Latino business survival in particular. To summarize the results, the estimations show that owner education and low barrier sectors are neutral in relationship to survival odds, that personal savings as source of start-up capital has positive association with survival, and

\footnotetext{
${ }^{13}$ The coefficients on other regional characteristics are robust to the exclusion of rurality codes.
} 
Puerto Rican ancestry is negatively associated with survival.

Table 6: Regional Characteristics: Survival Model Results

\begin{tabular}{|c|c|c|c|}
\hline Regional (county-level) Variables & $\begin{array}{c}\text { Cox Proportional } \\
\text { Hazards Model }\end{array}$ & $\begin{array}{l}\text { Exponential } \\
\text { Model }\end{array}$ & $\begin{array}{l}\text { Weibull } \\
\text { Model }\end{array}$ \\
\hline \multicolumn{4}{|l|}{ \% of population with education: } \\
\hline High school & $\begin{array}{l}1.01 \\
(0.01)\end{array}$ & $\begin{array}{l}1.01 \\
(0.01)\end{array}$ & $\begin{array}{c}1.01 \\
(0.01)\end{array}$ \\
\hline Some college & $\begin{array}{l}1.02^{* *} \\
(0.01)\end{array}$ & $\begin{array}{l}1.02^{* *} \\
(0.01)\end{array}$ & $\begin{array}{l}1.02^{* *} \\
(0.01)\end{array}$ \\
\hline Associate degree & $\begin{array}{c}1.01 \\
(0.01)\end{array}$ & $\begin{array}{l}1.01 \\
(0.01)\end{array}$ & $\begin{array}{c}1.00 \\
(0.01)\end{array}$ \\
\hline Bachelor's degree & $\begin{array}{l}1.00 \\
(0.01)\end{array}$ & $\begin{array}{l}1.00 \\
(0.01)\end{array}$ & $\begin{array}{c}1.00 \\
(0.01)\end{array}$ \\
\hline Graduate degree & $\begin{array}{c}1.01 \\
(0.01)\end{array}$ & $\begin{array}{l}1.01 \\
(0.01)\end{array}$ & $\begin{array}{c}1.01 \\
(0.01)\end{array}$ \\
\hline Per capita income & $\begin{array}{l}1.00 \\
(0.00)\end{array}$ & $\begin{array}{l}1.00 \\
(0.00)\end{array}$ & $\begin{array}{c}1.00 \\
(0.00)\end{array}$ \\
\hline Unemployment rate & $\begin{array}{l}1.01 \\
(0.01)\end{array}$ & $\begin{array}{c}1.01 \\
(0.01)\end{array}$ & $\begin{array}{c}1.01 \\
(0.01)\end{array}$ \\
\hline Labor force participation rate & $\begin{array}{l}1.00 \\
(0.00)\end{array}$ & $\begin{array}{l}1.00 \\
(0.00)\end{array}$ & $\begin{array}{l}1.00 \\
(0.00)\end{array}$ \\
\hline USDA rural-urban continuum code: & & & \\
\hline 2: Metro area, $0.25 \mathrm{M}$ to $1 \mathrm{M}$ pop. & $\begin{array}{l}1.06 \\
(0.04)\end{array}$ & $\begin{array}{l}1.06 \\
(0.04)\end{array}$ & $\begin{array}{c}1.06 \\
(0.04)\end{array}$ \\
\hline 3: Metro area, $<250,000$ & $\begin{array}{c}0.97 \\
(0.05)\end{array}$ & $\begin{array}{c}0.98 \\
(0.05)\end{array}$ & $\begin{array}{c}0.98 \\
(0.06)\end{array}$ \\
\hline 4: Adj. to metro, \geq 20,000 & $\begin{array}{c}1.01 \\
(0.07)\end{array}$ & $\begin{array}{c}1.01 \\
(0.07)\end{array}$ & $\begin{array}{c}1.01 \\
(0.08)\end{array}$ \\
\hline 5: Not adj. to metro, \geq 20,000 & $\begin{array}{l}1.00 \\
(0.10)\end{array}$ & $\begin{array}{l}1.00 \\
(0.10)\end{array}$ & $\begin{array}{c}0.99 \\
(0.10)\end{array}$ \\
\hline Adj. to metro, 2,500-19,999 & $\begin{array}{c}0.95 \\
(0.08)\end{array}$ & $\begin{array}{c}0.94 \\
(0.08)\end{array}$ & $\begin{array}{c}0.93 \\
(0.08)\end{array}$ \\
\hline Not adj. to metro, 2,500-19,999 & $\begin{array}{c}0.98 \\
(0.09)\end{array}$ & $\begin{array}{c}0.98 \\
(0.09)\end{array}$ & $\begin{array}{c}1.00 \\
(0.09)\end{array}$ \\
\hline Adj. to a metro, $<2,500$ & $\begin{array}{c}1.01 \\
(0.21)\end{array}$ & $\begin{array}{c}1.01 \\
(0.21)\end{array}$ & $\begin{array}{c}0.97 \\
(0.20)\end{array}$ \\
\hline Not adj. to a metro, $<2,500$ & $\begin{array}{c}0.82 \\
(0.16)\end{array}$ & $\begin{array}{c}0.81 \\
(0.16)\end{array}$ & $\begin{array}{c}0.81 \\
(0.17)\end{array}$ \\
\hline Observations & $\sim 127,000$ & $\sim 127,000$ & $\sim 127,000$ \\
\hline State FE & YES & YES & YES \\
\hline Year FE & YES & YES & YES \\
\hline
\end{tabular}

(C)Southern Regional Science Association 2019. 
The education and start-up capital findings in particular are different than one would expect from a panel of businesses selected without reference to ethnicity. Clearly policymakers wishing to bolster economic growth in an era when the share of Latinos in the US is expanding must take these differences into account. Some simple policy changes may help. For example, the finding that education is not related to survival rates is consistent with the idea of small-scale, primarily owner-labor standard business model enterprises even in business that are formalized. The challenge in working with these owners may be to find ways to reposition their accumulated informal business operations skills into sectors with more growth potential. Similarly, the finding that finance out of personal savings may point to a need to develop banking systems that better meet the situations of recent arrivals, who may arrive in the US with distrust of institutions. It could be that LOBs accumulate business capital before investing in other types of capital used to leverage business loans, e.g. housing. Mapping out capital accumulation strategies and educating the target population about these alternative mechanisms might result in higher survival rates.

Given the evidence that out-migrants from Puerto Rico are relatively low-skill, it may be that many of these migrants find themselves excluded from the labor market and turn to self-employment out of necessity rather than opportunity. The greater likelihood of exit follows logically. As we note above, Puerto Rican migrants experience in the continental United States is significantly different from that of Cuban and other Latino immigrants. The lower barriers to arrival may have impacts on the survival of businesses they start. For example, they might start a mainland non-employer service business during a lull on the island, and then return to Puerto Rico when new opportunities arise at home, or use the capital accumulated in operating their business to make investments in housing or businesses on the home island. However, the fact that the low survival is associated with lower (literal and figurative) barriers to entry might imply that business assistance organizations might seek mechanisms to measure ability to overcome barriers as part of the business counseling or in determining which businesses to assist. To counter churn among Puerto Rican-run businesses, local economic developers might help them instead find ways to sell viable enterprises in lieu of abandoning them, and work to network the group so they can learn from positive role models within their community.

Future research could more closely examine the cause of businesses exiting the data. While most exits are likely the result of failure, some may result from buy-out, a marketing change, or exit into employment. The role of federal contracting in exits could also be a topic of research. The finding that reliance on federal contracts reduces chances of survival stands in contrast to federal policies designed to encourage minority contracting. It is worth exploring further, perhaps via case studies, potential reasons for this outcome. For example, do the businesses fail due to lack of contract renewal? Do they fail due to burden of federal financial systems? Are they created as a kind of shell company in response to spot opportunities rather than sustained business niches? Each of these questions represent promising areas for future research.

(C)Southern Regional Science Association 2019. 


\section{REFERENCES}

Abel, Jaison R and Richard Deitz. (2014) "The Causes and Consequences of Puerto Rico's Declining Population," Current issues in Economics and Finance, 20.

Ahn, Taehyun. (2011) "Racial Differences in Self-employment Exits," Small Business Economics, 36, 169-186.

Andersson, Lina and Mats Hammarstedt. (2015) "Ethnic Enclaves, Networks and SelfEmployment among Middle Eastern Immigrants in Sweden," International Migration, 53, $27-40$.

Asoni, Andrea and Tino Sanandaji. (2016) "Identifying the Effect of College Education on Business and Employment Survival," Small Business Economics, 46, 311-324.

Audretsch, David B and Talat Mahmood. (1995) "New Firm Survival: New Results Using a Hazard Function," Review of Economics and Statistics.

Bates, Timothy and Timothy Mason Bates. (1997) Race, Self-employment, and Upward Mobility: An Illusive American Dream. Woodrow Wilson Center Press.

Bates, Timothy, Magnus Lofstrom, and Lisa J Servon. (2011) "Why Have Lending Programs Targeting Disadvantaged Small Business Borrowers Achieved So Little Success in the United States?," Economic Development Quarterly, 25, 255-266.

Bates, Timothy and Alicia Robb. (2013) "Greater Access to Capital is Needed to Unleash the Local Economic Development Potential of Minority-owned Businesses," Economic Development Quarterly, 27, 250-259.

Bernstein, Robert. (2016) "Hispanic-owned Businesses on the Upswing," Random Sampling.

Borjas, George J. (2008) "Labor Outflows and Labor Inflows in Puerto Rico," Journal of Human Capital, 2, 32-68.

Calo, Bea Violanda. (1995) Chicano Entrepreneurship in Rural California: An Empirical Analysis. University of California, Davis.

Carpenter, Craig. (2016) "The Dynamics of Latino-owned Business with Comparisons to Other Ethnicities," US Census Bureau Center for Economic Studies Paper No. CES-WP16-33.

Carrasco, Raquel. (1999) "Transitions to and from Self-employment in Spain: An Empirical Analysis," Oxford Bulletin of Economics and Statistics, 61, 315-341.

Cauchie, Grégoire and Nicolas Gérard Vaillant. (2016) "New Firm Survival: Isolating the Role of Founders Human Capital in Accounting for Firm Longevity," Journal of Human Capital, 10, 186-211.

Cavalluzzo, Ken and John Wolken. (2005) "Small Business Loan Turndowns, Personal Wealth, and Discrimination," The Journal of Business, 78, 2153-2178.

Center, Pew Research. (2006) "Cubans in the United States: Fact Sheet," .

Christie, Tamoya and David L Sjoquist. (2012) "New Business Survival in Georgia: Exploring the Determinants of Survival Using Regional Level Data," Growth and Change, 43, 110142.

Cox, David R. (1972) "Regression Models and Life-tables," Journal of the Royal Statistical Society: Series B (Methodological), 34, 187-202.

Cox, David R. (1975) "Partial Likelihood," Biometrika, 62, 269-276.

Dahl, Michael S and Toke Reichstein. (2007) "Are You Experienced? Prior Experience and the Survival of New Organizations," Industry and Innovation, 14, 497-511.

(C)Southern Regional Science Association 2019. 
Deller, Steven and Tessa Conroy. (2016) "Survival Rates of Rural Businesses: What the Evidence Tells Us," Choices, 31.

Dunne, Timothy, Mark J Roberts, and Larry Samuelson. (1989) "The Growth and Failure of US Manufacturing Plants," The Quarterly Journal of Economics, 104, 671-698.

Evans, David S. (1987) "Tests of Alternative Theories of Firm Growth," Journal of Political Economy, 95, 657-674.

Evans, David S and Linda S Leighton. (1989) "The Determinants of Changes in US Selfemployment, 1968-1987," Small Business Economics, 1, 111-119.

Fackler, Daniel, Claus Schnabel, and Joachim Wagner. (2013) "Establishment Exits in Germany: The Role of Size and Age," Small Business Economics, 41, 683-700.

Fairlie, Robert W. (2005) "Entrepreneurship among Disadvantaged Groups: An Analysis of the Dynamics of Self-employment by Gender, Race and Education," Handbook of Entrepreneurship, 2, 437-478.

Fairlie, Robert W and Alicia M Robb. (2009) "Gender Differences in Business Performance: Evidence from the Characteristics of Business Owners Survey," Small Business Economics, 33,375 .

Fertala, Nikolinka. (2008) "The Shadow of Death: Do Regional Differences Matter for Firm Survival across Native and Immigrant Entrepreneurs?," Empirica, 35, 59-80.

Ganotakis, Panagiotis. (2012) "Founders Human Capital and the Performance of UK New Technology Based Firms," Small Business Economics, 39, 495-515.

Georgellis, Yannis, John Sessions, and Nikolaos Tsitsianis. (2007) "Pecuniary and Nonpecuniary Aspects of Self-employment Survival," Quarterly Review of Economics and Finance, 47, 94-112.

Gonzalez-Barrera, Ana. (2016) "Apprehensions of Mexican Migrants at US Borders Reach Near-historic Low," Pew Research Center, Washington, DC.

Haapanen, Mika and Hannu Tervo. (2009) "Self-employment Duration in Urban and Rural Locations," Applied Economics, 41, 2449-2461.

Hansen, Eric L. (1995) "Entrepreneurial Networks and New Organization Growth," Entrepreneurship Theory and Practice, 19, 7-19.

Haynes, George W, Joseph I Onochie, and Yoon Lee. (2008) “Influence of Family's Social Relationships on the Debt Structure of Mexican-American and Korean-American Small Businesses," Journal of Developmental Entrepreneurship, 13, 343-361.

Krogstad, Jens Manuel. (2014) "With Fewer New Arrivals, Census Lowers Hispanic Population Projections," Washington, DC: Pew Research Center.

Krogstad, Jens Manuel. (2016) "Key Facts about How the US Hispanic Population is Changing," Pew Research Center.

Lechmann, Daniel SJ and Claus Schnabel. (2014) "Are the Self-employed Really Jacks-of-alltrades? Testing the Assumptions and Implications of Lazears Theory of Entrepreneurship with German Data," Small Business Economics, 42, 59-76.

Light, Ivan. (1979) "Disadvantaged Minorities in Self-employment," International Journal of Comparative Sociology, 20, 31.

Lin, Zhengxi, Garnett Picot, and Janice Compton. (2000) "The Entry and Exit Dynamics of Self-employment in Canada," Small Business Economics, 15, 105-125.

Liu, Cathy Yang. (2012) "The Causes and Dynamics of Minority Entrepreneurial Entry," Journal of Developmental Entrepreneurship, 17, 1250003.

(C)Southern Regional Science Association 2019. 
Lofstrom, Magnus and Timothy Bates. (2009) "Latina Entrepreneurship," Small Business Economics, 33, 427.

Millán, José María, Emilio Congregado, and Concepción Román. (2012) "Determinants of Self-employment Survival in Europe," Small Business Economics, 38, 231-258.

Millan, Jose Maria, Emilio Congregado, Concepcion Roman, Mirjam Van Praag, and Andre van Stel. (2014) "The Value of an Educated Population for an Individual's Entrepreneurship Success," Journal of Business Venturing, 29, 612-632.

Nziramasanga, Mudziviri and Minsoo Lee. (2001) "Duration of Self-employment in Developing Countries: Evidence from Small Enterprises in Zimbabwe," Small Business Economics, 17, 239-253.

Oberschachtsiek, Dirk. (2012) "The Experience of the Founder and Self-employment Duration: A Comparative Advantage Approach," Small Business Economics, 39, 1-17.

Patterson, Belinda and Cheryl McFadden. (2009) "Attrition in Online and Campus Degree Programs," Online Journal of Distance Learning Administration, 12, 1-8.

Peters, Michael P and Candida G Brush. (1996) "Market Information Scanning Activities and Growth in New Ventures: A Comparison of Service and Manufacturing Businesses," Journal of Business Research, 36, 81-89.

Puryear, Alvin N, Edward G Rogoff, Myung-Soo Lee, Ramona KZ Heck, Elissa B Grossman, George W Haynes, and Joseph Onochie. (2008) "Sampling Minority Business Owners and Their Families: The Understudied Entrepreneurial Experience," Journal of Small Business Management, 46, 422-455.

Raijman, Rebeca and Marta Tienda. (2000) "Immigrants Pathways to Business Ownership: A Comparative Ethnic Perspective," International Migration Review, 34, 682-706.

Ramirez de Miess, Norma. (2009) "The Impact of Multicultural Presence in the US with a Focus on Hispanic Growth, Latino Business Development and Entrepreneurship in Iowa," Town/Craft Roundtable Discussion Report.

Robb, Alicia M and Robert W Fairlie. (2007) "Access to Financial Capital among US Businesses: The Case of African American Firms," The Annals of the American Academy of Political and Social Science, 613, 47-72.

Robb, Alicia M and Robert W Fairlie. (2009) "Determinants of Business Success: An Examination of Asian-owned Businesses in the USA," Journal of Population Economics, 22, 827.

Robles, Barbara J and Hector Cordero-Guzman. (2007) "Latino Self-employment and Entrepreneurship in the United States: An Overview of the Literature and Data Sources," The Annals of the American Academy of Political and Social Science, 613, 18-31.

Rocha, Vera, Anabela Carneiro, and Celeste Amorim Varum. (2015) "Entry and Exit Dynamics of Nascent Business Owners," Small Business Economics, 45, 63-84.

Rosenthal, Stuart S and William C Strange. (2012) "Female Entrepreneurship, Agglomeration, and a New Spatial Mismatch," Review of Economics and Statistics, 94, 764-788.

Rusin, Sylvia, Jie Zong and Jeanne Batalova. (2015) "Cuban Immigrants in the United States," Migration Policy Institute.

Taylor, Mark P. (1999) "Survival of the Fittest? An Analysis of Self-employment Duration in Britain," Economic Journal, 109, 140-155.

U.S. Census Bureau. (2010) Survey of Business Owners Hispanic-Owned Firms: $200 \%$.

Van Praag, C Mirjam. (2003) "Business Survival and Success of Young Small Business

(C)Southern Regional Science Association 2019. 
Owners," Small Business Economics, 21, 1-17.

Waldinger, Roger. (1993) "Reply to Bonacich: The Two Sides of Ethnic Entrepreneurship," International Migration Review, 27, 692-701.

Walton-Roberts, Margaret and Daniel Hiebert. (1997) "Immigration, Entrepreneurship, and the Family: Indo-Canadian Enterprise in the Construction Industry of Greater Vancouver," Canadian Journal of Regional Science, 20, 119-39.

(C)Southern Regional Science Association 2019. 


\section{APPENDIX}

Table 7: FSRDC Variable Data Sources

\begin{tabular}{|c|c|c|c|c|c|c|}
\hline Dataset & $\begin{array}{l}\text { Data } \\
\text { Structure }\end{array}$ & Universe & $\begin{array}{l}\text { Unit of } \\
\text { Observation }\end{array}$ & $\begin{array}{l}\text { Match } \\
\text { variable }\end{array}$ & Years & $\begin{array}{l}\text { Characteristic } \\
\text { variables }\end{array}$ \\
\hline $\mathrm{SBO}$ & $\begin{array}{l}\text { Cross } \\
\text { Section }\end{array}$ & $\begin{array}{l}\text { Employer and non- } \\
\text { employer firms }\end{array}$ & Establishment & Firm & 2002 & $\begin{array}{l}\text { Business ownel } \\
\text { and business }\end{array}$ \\
\hline LBD & Panel & Employer firms & Establishment & Firm & $\begin{array}{l}2002- \\
2006\end{array}$ & Business \\
\hline ILBD & Panel & $\begin{array}{l}\text { Non-employer } \\
\text { firms }\end{array}$ & Establishment & Firm & $\begin{array}{l}2002- \\
2006\end{array}$ & Business \\
\hline
\end{tabular}

Abbrev. Survey of Business Owners (SBO), Integrated Longitudinal Database (ILBD), Federal Statistical Research Data Center (FSRDC), Longitudinal Business Database (LBD). Note: Business age, multiple establishment indicators, and NAICS classification can be derived from all of the datasets, but previous work in the FSRDC has focused data-cleaning efforts on the LBD, so this work uses the LBD for variables with multiple potential sources, though differences were minimal.

(C)Southern Regional Science Association 2019. 